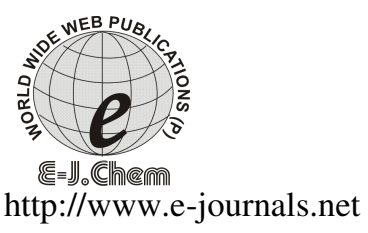

\title{
Estimation of Ziprasidone Hydrochloride Monohydrate in Bulk and Capsules by Reverse Phase HPLC
}

\author{
B. SUDHA RANI* and P.VENKATA REDDY \\ College of Pharmaceutical Sciences, \\ Andhra University, \\ Visakhapatnam-530003 (India).
}

Received 4 March 2006; Accepted 23 June 2006.

\begin{abstract}
A reverse phase HPLC method is described for the determination of Ziprasidone $\mathrm{HCl}$ mono hydrate in bulk and pharmaceutical dosage forms. Chromatography was carried out on an ODS C18 column using a mixture of methanol and phosphate buffer $(55: 45 \mathrm{v} / \mathrm{v})$ as the mobile phase at a flow rate of $1 \mathrm{~mL} / \mathrm{min}$. Detection was carried out at $314 \mathrm{~nm}$. The retension time of the drug was $4.522 \mathrm{~min}$. The method produced linear responses in the concentration range of 0.5-30 $\mu \mathrm{g} / \mathrm{mL}$ of Ziprasidone $\mathrm{HCl}$ mono hydrate. The method was found to be applicable for determination of the drug in capsules.
\end{abstract}

Keywords: Ziprasidone, Estimation, HPLC.

\section{Introduction}

Ziprasidone $\mathrm{HCl}$ is chemically named as 5-[2-[4-(1,2 benzisothiazol-3-yl)-1Piperazinyl]ethyl]-6-chloro-1,3-dihydro-2h-indol-2-one. It is a novel anti psychotic exhibits a potent highly selective antagonistic activity on the D2 and 5HT2 receptors. A few analytical methods published that describe the quantification of Ziprasidone in plasma by liquid chromatography, fluorescence detection, and UV detection. In the present investigation the authors propose a simple, sensitive and reproducible method for the determination of Ziprasidone hydrochloride monohydrate. 


\section{Experimental}

\section{Chemicals and solvents}

HPLC grade methanol (Qualigens), Potassium dihydrogen phosphate and disodium hydrogen phosphate and Orthophosphoric acid (AR grade,Qualigens) were used for preparing the mobile phase. Pure samples of Ziprasidone $\mathrm{HCl}$ (Ranbaxy) and commercial samples of capsules containing Ziprasidone namely Azona-20 (Torrent), were employed in the study.

\section{Chromatographic conditions}

A gradient HPLC system (Waters) with waters 1525 binary HPLC pump. Waters 2487 UV dual y absorbance detector, waters breeze software and RP C18 column (150, $4.6 \mathrm{~mm}$ I.D, W03281S024, particle size $5 \mathrm{um}$ ) was used. Freshly prepared 55:45 v/v mixture of methanol and phosphate buffer $(p \mathrm{H} \mathrm{3.2)}$ was used as the mobile phase. Both methanol and phosphate buffer were filtered through $0.45 \mathrm{um}$ membrane filter and sonicated before use. The flow rate of the mobile phase was maintained at $1 \mathrm{~mL} / \mathrm{min}$. The detection was carried out at $314 \mathrm{~nm}$.

\section{Estimation of Ziprasidone $\mathrm{HCl}$ mono hydrate}

About $56.6 \mathrm{mg}$ of Ziprasidone $\mathrm{Hcl}$ monohydrate was weighed accurately and transferred into a $50 \mathrm{~mL}$ volumetric flask and dissolved in $25 \mathrm{~mL}$ methanol. The solution was sonicated for 15 min and then the volume made up with a further quantity of the methanol to give $1 \mathrm{mg} / \mathrm{mL}$. Subsequent dilutions of this solution ranging from $0.5-40 \mu \mathrm{g} / \mathrm{mL}$ were made in $10 \mathrm{~mL}$ volumetric flasks, with the mobile phase. $20 \mathrm{uL}$ of the solution was injected each time into the column at a flow rate of $1 \mathrm{~mL} / \mathrm{min}$. Each of the dilutions was injected five times into the column and the corresponding chromatograms were obtained. From these chromatograms, the retention times and the areas under the peaks of the drug were noted. The regression equation was used to estimate the amount of drug present in pharmaceutical dosage forms.

To check the intra and inter- day variation of the method, solutions containing 8, 12, 20 $\mu \mathrm{g} / \mathrm{mL}$ of Ziprasidone were subjected to the proposed HPLC analysis (Table-3).

\section{Estimation of the Drug in Capsule Dosage Forms}

Two commercial brands of capsules namely Azona (Torrent) were chosen for testing the suitability of the proposed method to estimate Ziprasidone in capsule formulations. For this, 20 capsules were weighed and powdered. An accurately weighed portion of this powder equivalent to $50 \mathrm{mg}$ of Ziprasidone was transferred to a $50 \mathrm{~mL}$ volumetric flasks containing $25 \mathrm{~mL}$ methanol. The contents were allowed to stand for $1 / 2 \mathrm{~h}$ with intermittent sonication to ensure complete solubility of the drug and then filtered through 0.45 um membrane filter. Appropriate volume of this filtrate equivalent to $10 \mu \mathrm{g} / \mathrm{mL}$ of the drug was taken in a $10 \mathrm{~mL}$ volumetric flask. The contents of the flask were made up to the volume with the mobile phase and mixed well. $20 \mathrm{uL}$ of the solution was then injected into the column. The mean peak area of the drug of five such determinations was calculated and the drug content in the capsules was quantified using the regression equation obtained for the pure sample.

\section{Results and Discussion}

The present study was aimed at developing a sensitive, precise and accurate HPLC method for the analysis of Ziprasidone in pharmaceutical dosage forms. For this, a binary mixture of methanol and phosphate buffer $(55: 45 \mathrm{v} / \mathrm{v})$ portion was found to be the most suitable mobile phase as the chromatographic peaks obtained with this system were better defined and 
resolved and all almost free from tailing. Under the above-mentioned conditions, the retention time obtained for Ziprasidone was $4.48 \mathrm{~min}$. A model chromatogram was shown in Figure 1.

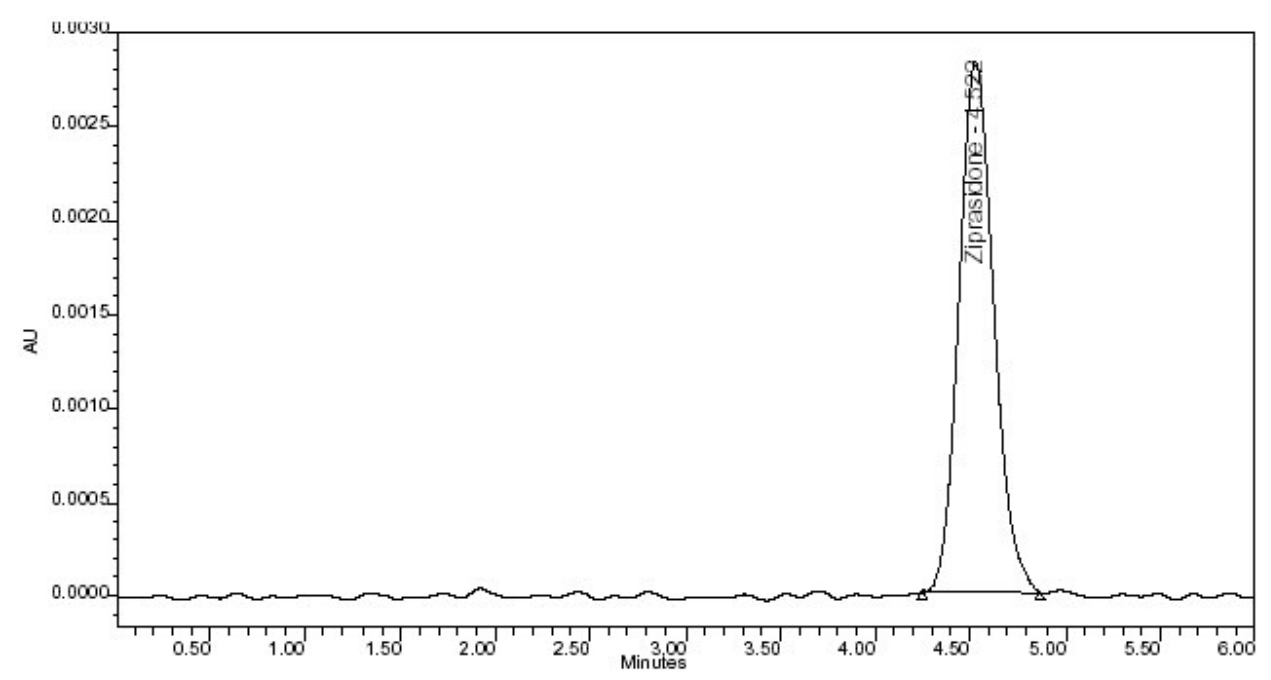

Figure 1. A model chromatogram of Ziprasidone hydrochloride monohydrate $2 \mu \mathrm{g}$

The peak areas of the drug were reproducible as indicated by low coefficient of variation $(1.2 \%)$ shown in Table-1. A good linear relationship $(r=0.999)$ was observed between the concentrations of Ziprasidone and respective peak areas. The regression curve was constructed by linear regression fitting and its mathematical expression was

The regression characteristics were given in Table-2. The intra and inter-day drug variation studies by the proposed HPLC method showed low coefficient of variation as shown in Table-3. The drug content in the capsules was quantified using the proposed analytical method. The mean amount of Ziprasidone obtained in capsule dosage forms is shown in Table-4. This reveals that the method is quite precise. The absence of additional peaks in the chromatogram indicates non-interference of the common excipients used in the capsules.

It can be concluded that the proposed HPLC method is sensitive and reproducible for the analysis of Ziprasidone Hcl monohydrate in pharmaceutical dosage forms in a short analysis time. The method was duly validated by evaluation of the required parameters.

Table-1 Calibration of the Proposed Method

\begin{tabular}{cc}
\hline Concentration of Ziprasidone $(\mu \mathrm{g} / \mathrm{mL})$ & Coefficient of variation \% \\
\hline 0.5 & 0.62 \\
1.0 & 0.73 \\
2.0 & 0.96 \\
5.0 & 1.22 \\
10.0 & 1.02 \\
20.0 & 0.68 \\
\hline
\end{tabular}


Table 2. Regression Characterstics of the Proposed HPLC Method

\begin{tabular}{ll}
\hline \multicolumn{1}{c}{ Parameters } & Value \\
\hline Standard deviation on slope (Sb) & 0.00549 \\
Standard deviation on intercept (Sa) & 0.00280 \\
Standard error of estimation (Se) & 0.00431 \\
Relative standard deviation (\%) & 1.2430 \\
$\%$ range of error at 95\% confidence limit & 1.31470 \\
$\%$ range of error at 99\% confidence limit & 1.94510 \\
Slope (a) & 0.09540 \\
Intercept (b) & 0.10034 \\
Correlation coefficient (r) & 0.9990 \\
\hline
\end{tabular}

Table 3. Intra and Interday Precision of the Proposed Method

\begin{tabular}{|c|c|c|c|c|}
\hline \multirow{3}{*}{$\begin{array}{l}\text { Concentration of } \\
\text { Ziprasidone } \mathrm{HCl} \\
\text { monohydrate }(\mu \mathrm{g} / \mathrm{mL})\end{array}$} & \multicolumn{4}{|c|}{ Observed concentration of Ziprsidone $\mathrm{HCl}(\mu \mathrm{g} / \mathrm{mL})$} \\
\hline & \multicolumn{2}{|c|}{ Intra day } & \multicolumn{2}{|c|}{ Interday } \\
\hline & Mean & RSD & Mean & RSD \\
\hline 8 & 7.98 & 0.68 & 8.03 & 0.35 \\
\hline 12 & 12.18 & 0.75 & 12.05 & 1.44 \\
\hline 20 & 20.04 & 1.43 & 19.98 & 0.93 \\
\hline
\end{tabular}

Table-4. Assay of Terbinafine Hydrochloride in Capsule Dosage Forms

\begin{tabular}{llll}
\hline $\begin{array}{l}\text { Brand name } \\
\text { of the capsule }\end{array}$ & $\begin{array}{l}\text { Labeled amount } \\
\text { of drug } \\
(\mathrm{mg})\end{array}$ & $\begin{array}{l}\text { Mean }(+\mathrm{S} . \mathrm{D}) \text { amount } \\
\text { found }(\mathrm{mg}) \text { by the } \\
\text { proposed method }\end{array}$ & $\begin{array}{l}\text { Mean }(+\mathrm{S} . \mathrm{d}) \% \\
\text { labeled amount }(\mathrm{n}=5)\end{array}$ \\
\hline Azona & 20 & $20.01 \pm 0.011$ & $100.05 \pm 0.023$ \\
Zipsydone & 40 & $39.95 \pm 0.084$ & $99.87 \pm 0.12$ \\
\hline
\end{tabular}

\section{References}

1. Raymond Suckow F, Mira Fein, Christoph Corell U and Thomas Cooper B, Journal of chromatography B, 2004,799, 201-208.

2. Sachse, Julia, Hartter, Sebastian, Hiemke and Christoph, Therauptic drug monitoring, 2005, 27(2), 158-162.

3. Janiszeski J S, Fouda H G and Cole R O, Journal of chromatography, 1995, 668, 133.

4. Lasko H A, Therauptic drug monitoring, 2001, 23, 454.

5. Janiszeski J, Schneider R P, Hoffmaster K, Swyden M, Wells D and Fouda H, Rapid commun.Mass spectrum.1997, 11,1033. 


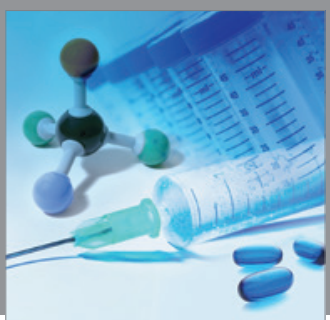

International Journal of

Medicinal Chemistry

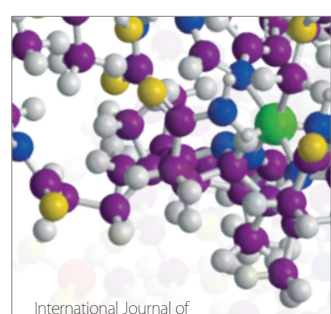

Carbohydrate Chemistry

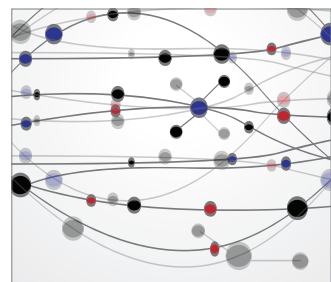

The Scientific World Journal
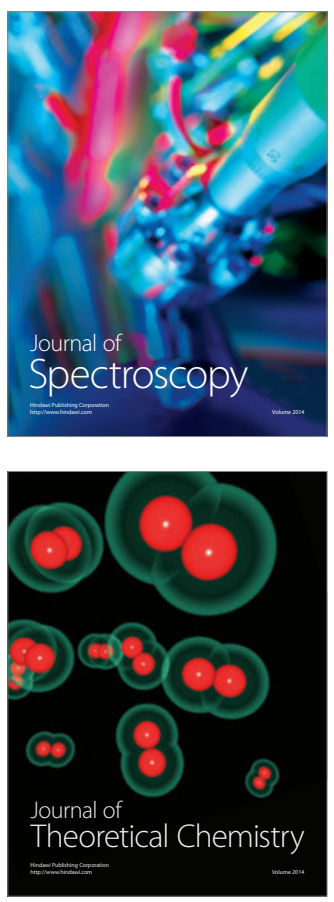
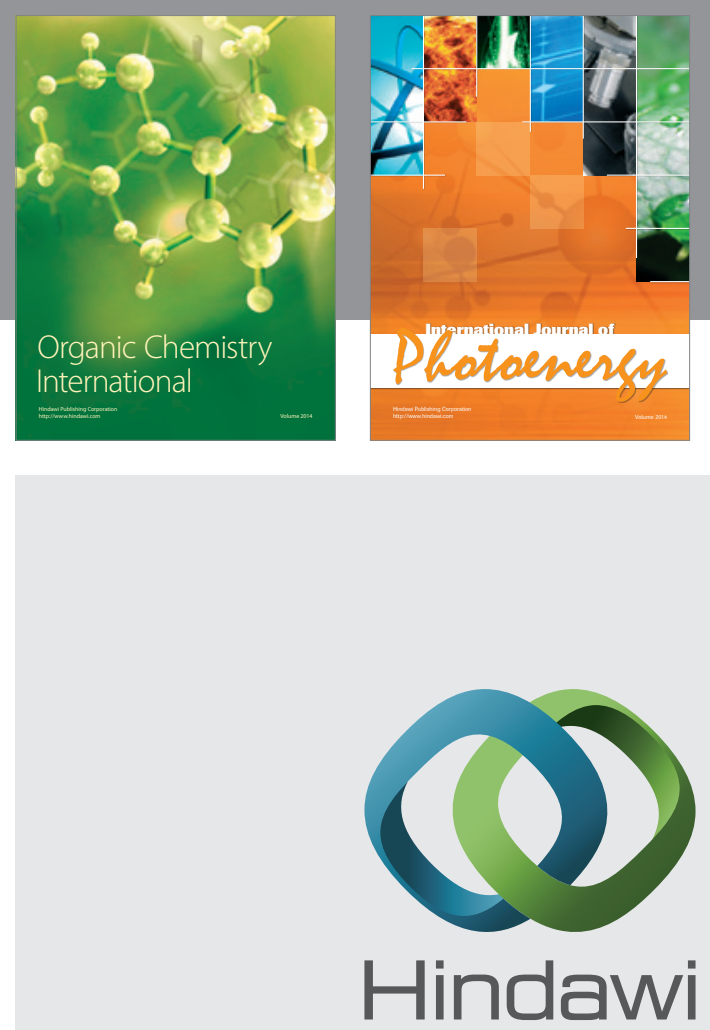

Submit your manuscripts at

http://www.hindawi.com
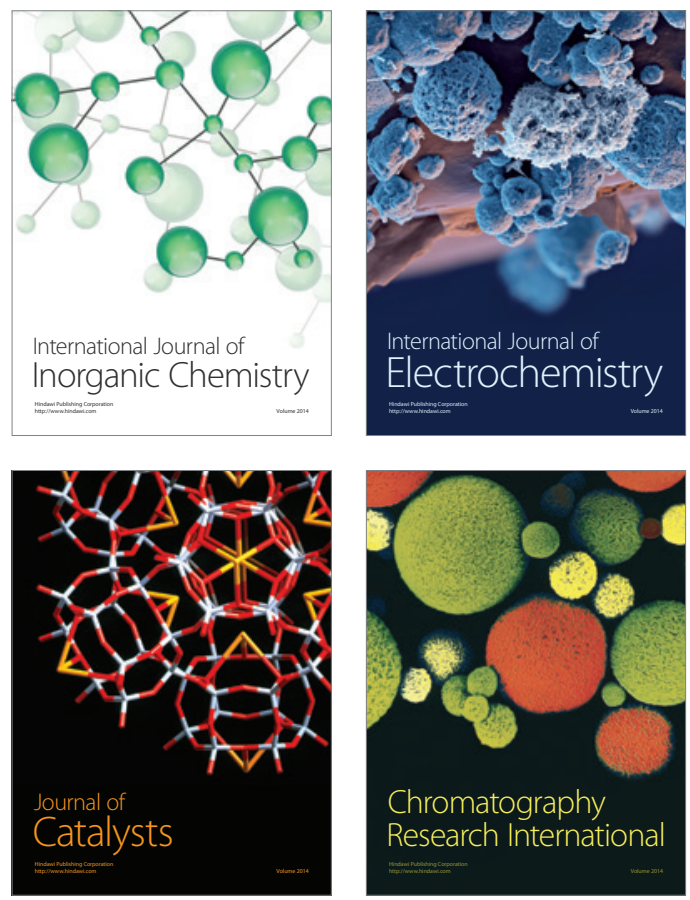
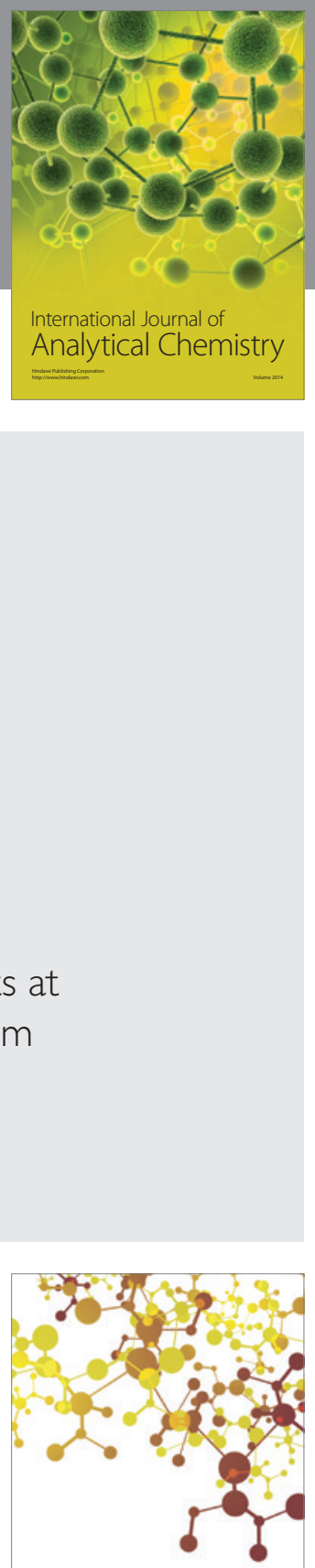

Journal of

Applied Chemistry
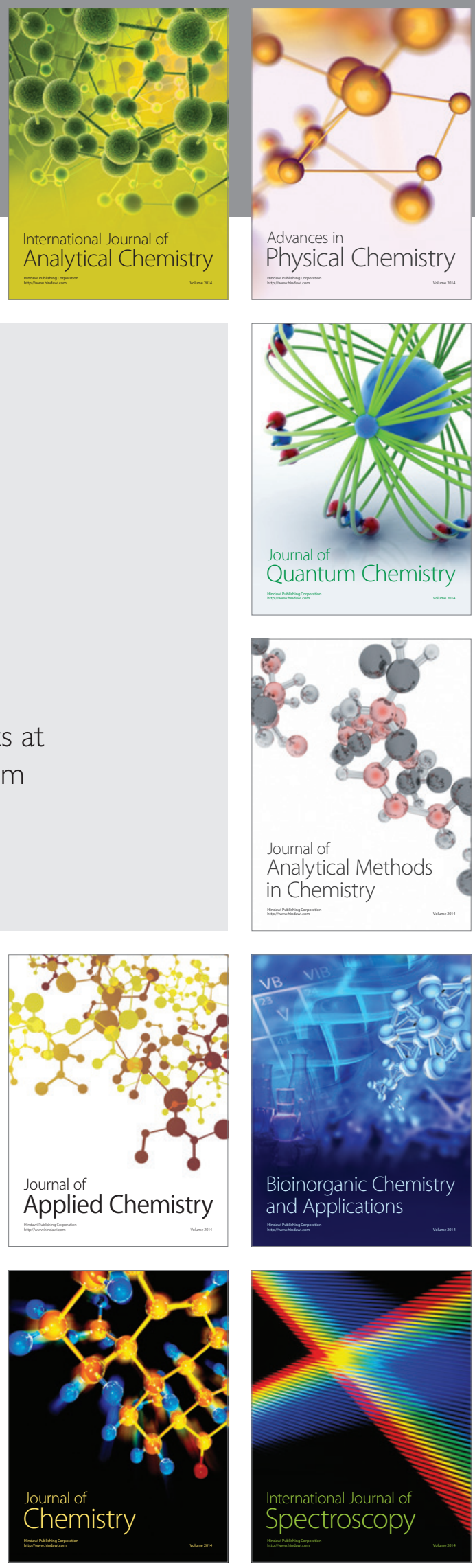